\title{
The analysis of bacteriologically negative congenital infections in neonates with regard to the type of labour and intrapartum antibiotic prophylaxis
}

\author{
Sławomir Szymański , Katarzyna Szczerba², Olimpia Sipak-Szmigiel ${ }^{1}$ \\ 'Department of Obstetrics and Pathology of Pregnancy, Pomeranian Medical University in Szczecin, Szczecin, Poland \\ ${ }^{2}$ Department of Gynaecology and Obstetrics, Regional Hospital in Kolobrzeg, Kolobrzeg, Poland
}

\section{ABSTRACT}

\begin{abstract}
Aim of the study: To analyse neonates with bacteriologically negative congenital infections with regard to the type of labour and intrapartum antibiotic prophylaxis (IAP).

Material and methods: The research material included the medical history data of 1328 born-alive neonates from single pregnancies, and the data of their mothers. A $\chi^{2}$ test (also with Yates correction) was employed to perform fraction analysis. The level of significance was set at $p<0.05$.

Results: The neonates with congenital infections were hospitalised for considerably longer than the uninfected ones irrespective of whether they were born vaginally $(p<0.001)$ or via $\mathrm{C}$-section $(p<0.0007)$. The uninfected neonates scored significantly higher on the Apgar scale $(p<0.0001) .1 .23 \%$ of the mothers who did not receive IAP and $3.37 \%$ of those who received IAP gave birth to ill neonates. The total percentage of infants with clinically confirmed infections was $1.81 \%(p=0.0096)$. Clinically confirmed congenital infections were found in $1.13 \%$ of the neonates from vaginal labours and $4.55 \%$ of those born via $C$-section $(p=0.0001)$.

Conclusions: Early symptomatic infections in neonates can develop without positive bacteriological culture results. IAP can modify the occurrence and/or the course of clinically confirmed congenital infections. Empirical antibiotic treatment of infections administered during the first 24 hours does not seem to be the best solution; however, currently it is necessary. The colour of amniotic fluid and the type of labour, especially when accompanied by other risk factors, may suggest an infection.
\end{abstract}

\section{KEY WORDS:}

infection, culture, labour, antibiotic treatment.

\section{INTRODUCTION}

The last decade has witnessed a gradual decline in perinatal morbidity and mortality of foetuses and neonates. This seems to be partly due to intrapartum antibiotic prophylaxis (IAP), implemented to prevent
Streptococcus agalactiae infections $[1,2]$. A still existing problem, however, is a bacteriologically non-confirmed congenital infection that is a clinical state when inflammation manifests itself in clinical and laboratory symptoms despite negative bacteriological culture results.

\section{ADDRESS FOR CORRESPONDENCE:}

Sławomir Szymański, Department of Obstetrics and Pathology of Pregnancy, Pomeranian Medical University in Szczecin, 48 Żołnierska St., 71-210 Szczecin, Poland, ORCID: 0000-0002-1127-9567, e-mail: sszymanski@o2.pl 


\section{AIM OF THE STUDY}

The purpose of this study was to analyse neonates with bacteriologically non-confirmed congenital infections with regard to risk factors and intrapartum procedures, including IAP.

\section{MATERIAL AND METHODS}

The research material included medical history data of 1328 born-alive neonates from single pregnancies, and the data of their mothers. The childbirths analysed in this study took place in the Regional Hospital in Kolobrzeg in 2011 (at which time the recommendations of the Polish Gynaecological Society concerning the prevention of group B Streptococcus [GBS] infections in neonates had been implemented to everyday medical practice) and in 2007 (at which time the prophylaxis of GBS infections in neonates was not common). A bacteriologically non-confirmed congenital infection is regarded as a state when a neonate exhibits symptoms such as breathing problems, pale skin, sucking problems, episodes of convulsions, and coryza, despite negative culture results. Laboratory analysis revealed elevated inflammatory parameters, including C-reactive protein (CRP) and procalcitonin (PCT).

Statistical analysis was performed using Statistica PL v. 10.0 (StatSoft, USA). The tested continuous parameters were described as the number of neonates, the arithmetic mean, and the standard deviation. Discrete (qualitative) parameters were shown as percentages (fractions). Student's t-test was applied to compare arithmetic means between the groups. Fraction analysis was performed using Student's t-test and the $\chi^{2}$ test (also with Yates correction). The level of statistical significance was set at $p<0.05$.

\section{RESULTS}

The number of births was significantly lower for women whose babies had a clinically confirmed congenital infection than for their counterparts who gave birth to uninfected infants $(p<0.02)$. The neonates with congenital infections were hospitalised for considerably longer periods than the uninfected ones, irrespective of whether they were born vaginally $(p<0.001)$ or via C-section $(p<0.0007)$. The uninfected neonates scored significantly higher on the Apgar scale $(p<0.0001)$. As for other parameters, no statistically significant differences were observed (Table 1).

$1.23 \%$ of the mothers who did not receive IAP and $3.37 \%$ of those who received IAP gave birth to ill neonates. The total percentage of infants with clinically confirmed infections was $1.81 \%$. The differences were statistically significant $(p=0.0096)$ (Table 2 ).

Clinically confirmed congenital infections were diagnosed in: $0.46 \%$ of the neonates born to the GBS-untested mothers who were not given IAP, and $2.58 \%$ born to mothers who received IAP - the differences were statistically significant ( $p=0.0076) ; 2.77 \%$ of the neonates born to the GBS-negative women who did not receive IAP, and none of the neonates born to such women who received IAP - the differences were not statistically significant; $3.03 \%$ of the neonates born to the GBS-positive women who did not receive IAP, and $5.83 \%$ born to such women who received IAP - the differences were not statistically significant (Table 3).

Clinically confirmed congenital infections were found in $1.13 \%$ of the neonates from vaginal labours and $4.55 \%$ of those born via $\mathrm{C}$-section. The difference was statistically significant $(p=0.0001)$ (Table 4$)$.

TABLE 1. The general data of the tested population

\begin{tabular}{|c|c|c|c|c|c|c|c|}
\hline \multirow[t]{3}{*}{ General data } & \multicolumn{6}{|c|}{ Neonate } & \multirow[t]{3}{*}{$p^{*}$} \\
\hline & \multicolumn{3}{|c|}{ Healthy } & \multicolumn{3}{|c|}{ III } & \\
\hline & Mean & SD & $n$ & Mean & SD & $n$ & \\
\hline Number of births & 1.6 & 0.9 & 1304 & 1.2 & 0.4 & 24 & $<0.02$ \\
\hline Duration of pregnancy (weeks) & 39.2 & 1.6 & 1304 & 39.5 & 1.7 & 24 & NS \\
\hline $\begin{array}{l}\text { Hospitalisation of neonates after } \\
\text { vaginal labour ( } 24 \text { hours) }\end{array}$ & 3.9 & 2.7 & 1052 & 8.4 & 1 & 12 & $<0.0001$ \\
\hline $\begin{array}{l}\text { Hospitalization of neonates after } \\
\text { C-section ( } 24 \text { hours) }\end{array}$ & 5.7 & 2.1 & 252 & 7.9 & 2.4 & 12 & $<0.0007$ \\
\hline $\begin{array}{l}\text { Total duration of the vaginal labour } \\
\text { (minutes) }\end{array}$ & 386.7 & 193.7 & 1049 & 492.1 & 151 & 12 & NS \\
\hline $\begin{array}{l}\text { Total duration of all labours from } \\
\text { PROM (minutes) }\end{array}$ & 354.5 & 931.6 & 1156 & 207.7 & 276.2 & 18 & NS \\
\hline The infant's score on the Apgar scale & 9.3 & 1.2 & 1304 & 8.1 & 1.7 & 24 & $<0.0001$ \\
\hline Neonates'body weight (grams) & 3378 & 521 & 1304 & 3517 & 624 & 24 & NS \\
\hline
\end{tabular}

$S D$ - standard deviation, PROM - premature rupture of membranes, NS - not significant, ${ }^{*}$ Student's $t$-test 
TABLE 2. Intrapartum antibiotic prophylaxis and the occurrence of infections in the neonates

\begin{tabular}{|c|c|c|c|c|c|c|}
\hline \multirow{2}{*}{$\begin{array}{l}\text { Treatment of } \\
\text { pregnant women }\end{array}$} & \multicolumn{2}{|c|}{ Healthy neonates } & \multicolumn{2}{|c|}{ III neonates } & \multicolumn{2}{|c|}{ Total } \\
\hline & $n$ & $\%$ & $n$ & $\%$ & $n$ & $\%$ \\
\hline No IAP & 960 & 98.77 & 12 & 1.23 & 972 & 100 \\
\hline IAP & 344 & 96.63 & 12 & 3.37 & 356 & 100 \\
\hline Total & 1304 & 98.19 & 24 & 1.81 & 1328 & 100 \\
\hline \multicolumn{7}{|c|}{$p^{*}=0.0096$} \\
\hline
\end{tabular}

IAP-intrapartum antibiotic prophylaxis, ${ }^{*} \chi^{2}$ test

TABLE 3. Intrapartum antibiotic prophylaxis with regard to smear test results and bacteriologically negative congenital infections in the neonates

\begin{tabular}{|c|c|c|c|c|c|c|c|}
\hline \multirow{2}{*}{\multicolumn{2}{|c|}{ GBS }} & \multicolumn{2}{|c|}{ Healthy neonates } & \multicolumn{2}{|c|}{ III neonates } & \multicolumn{2}{|c|}{ Total } \\
\hline & & $n$ & $\%$ & $n$ & $\%$ & $n$ & $\%$ \\
\hline \multirow{3}{*}{$\begin{array}{l}\text { Unknown } \\
\text { GBS status } \\
\text { (no tests) }\end{array}$} & No IAP & 647 & 99.54 & 3 & 0.46 & 650 & 100 \\
\hline & IAP & 189 & 97.42 & 5 & 2.58 & 194 & 100 \\
\hline & Total & 836 & 99.05 & 8 & 0.95 & 844 & 100 \\
\hline \multicolumn{8}{|c|}{$p^{*}=0.0076$} \\
\hline \multirow[t]{3}{*}{ Negative } & No IAP & 281 & 97.23 & 8 & 2.77 & 289 & 100 \\
\hline & IAP & 42 & 100 & 0 & 0 & 42 & 100 \\
\hline & Total & 323 & 97.58 & 8 & 2.42 & 331 & 100 \\
\hline \multicolumn{8}{|c|}{$N S^{*}$} \\
\hline \multirow[t]{3}{*}{ Positive } & No IAP & 32 & 96.97 & 1 & 3.03 & 33 & 100 \\
\hline & IAP & 113 & 94.17 & 7 & 5.83 & 120 & 100 \\
\hline & Total & 145 & 94.77 & 8 & 5.23 & 153 & 100 \\
\hline \multicolumn{8}{|c|}{$N S^{*}$} \\
\hline
\end{tabular}

GBS - group B Streptococcus, IAP - intrapartum antibiotic prophylaxis, NS - not significant, ${ }^{*} \chi^{2}$ test

TABLE 4. The type of labour and bacteriologically negative congenital infections in the neonates

\begin{tabular}{|l|c|c|c|c|c|c|}
\hline \multirow{2}{*}{ Type of labour } & \multicolumn{2}{|c|}{ Healthy neonates } & \multicolumn{2}{c|}{ III neonates } \\
\cline { 2 - 7 } & $n$ & $\%$ & $n$ & 1.13 & 1064 & 100 \\
\hline VL & 1052 & 98.87 & 12 & 4.55 & 264 & 100 \\
\hline CS & 252 & 95.45 & 12 & 1.81 & 1328 & 100 \\
\hline Total & 1304 & 98.19 & 24 & $p^{*}=0.0001$ \\
\hline \multicolumn{7}{|l|}{} \\
\hline
\end{tabular}

${ }^{*} \chi^{2}$ test, $V L$ - vaginal labour, $C S-C$-section

Clear amniotic fluid was observed in $1.68 \%$ of the ill neonates, and green in $3.01 \%$. The difference was not statistically significant (Table 5).

\section{DISCUSSION}

Compliance with the guidelines of the Polish Gynaecological Society concerning the detection of GBS in pregnant women, and the prevention of neonatal infections has resulted in more frequent usage of IAP, and thus a decline in the incidence of early onset GBS symptomatic infections among neonates [1]. However, because other consequences of common antibiotic treatment have not been tested yet, it is possible that using this partly empirical treatment will bring unintended and unfavourable effects, such as early microbiologically non-confirmed infections in neonates, and higher utilisation of antibiotic treatment in babies born to women receiving IAP. Also, the duration of hospitalisation of neonates and their mothers receiving antibiotics during labour, as well as the cost of such treatment, require thorough analysis. Some studies show that babies of mothers receiving IAP are more often subjected to laboratory tests and empirical antibiotic treatment after birth. According to other reports, the recommendations of the Centres for Disease Control and Prevention (CDC) have not caused an in- 
TABLE 5. The colour of amniotic fluid and bacteriologically negative congenital infections in the neonates

\begin{tabular}{|c|c|c|c|c|c|c|}
\hline \multirow{2}{*}{$\begin{array}{l}\text { Colour of amniotic } \\
\text { fluid }\end{array}$} & \multicolumn{2}{|c|}{ Healthy neonates } & \multicolumn{2}{|c|}{ III neonates } & \multicolumn{2}{|c|}{ Total } \\
\hline & $n$ & $\%$ & $n$ & $\%$ & $n$ & $\%$ \\
\hline Clear & 1175 & 98.32 & 20 & 1.68 & 1195 & 100 \\
\hline Green & 129 & 96.99 & 4 & 3.01 & 133 & 100 \\
\hline Total & 1304 & 98.19 & 24 & 1.81 & 1328 & 100 \\
\hline \multicolumn{7}{|c|}{$N S^{*}$} \\
\hline
\end{tabular}

${ }^{*} \chi^{2}$ test

crease in the number of diagnoses of microbiologically non-confirmed neonatal infections, but only higher costs of treatment and longer hospital stays [3-7].

Glasgow et al., who analysed data of more than 130,000 full-term neonates from single pregnancies, devoted a lot of attention to newborns with so-called 'clinical sepsis'. They assumed that neonates with 'clinical sepsis' were those receiving intravenous antibiotic treatment after birth for over 72 hours (irrespective of bacteriological smear results). Additionally, they singled out neonates from the so-called "rule out" group, i.e. those in whom sepsis was excluded, and so antibiotic treatment was stopped after 48 hours due to improvement of their clinical state and negative smear results. These authors observed that some paediatricians continued to use antibiotics despite the improvement of the neonates' clinical state and negative smear results, because they assumed the possibility of developing sepsis due to the clinical course and symptoms occurring immediately after birth, as well as current abnormal laboratory test results. Glasgow et al. reported that the gradually increasing use of intrapartum antibiotics for GBS (from 75\% in 1998 to $91 \%$ in 2002) and a higher detection rate for GBS in pregnant women (from 1.9\% in 1998 to $13.8 \%$ in 2002) were accompanied by more frequent diagnoses of 'clinical sepsis' (from $1.2 \%$ in 1998 to $1.4 \%$ in 2002) and a higher proportion of infants born to IAP mothers in whom empirical treatment with antibiotics was stopped after 48 hours (from $3.3 \%$ in 1998 to $4.5 \%$ in 2002). The authors suggested that paediatricians may have a 'lower threshold of using empirical antibiotic treatment' in neonates subjected to IAP in their mothers' wombs. They noticed that 'clinical sepsis' had been more often diagnosed, and empirical antibiotic treatment had been more often applied in infants born to GBS-carriers receiving IAP and women with chorioamnionitis, as well as those born via C-section. In Glasgow's study, despite a substantial increase in the frequency of giving IAP to women during delivery, the number of neonates treated according to the scheme applied in newborns with early symptomatic sepsis did not reduce [8]. Also, in our study, the more frequent administration of intrapartum antibiotics in 2011, and a higher detection rate for GBS in pregnant women, involved more numerous diagnoses of intrauterine infections in neonates, confirmed clinically but not microbi- ologically $(p<0.0001)$. We found that the percentage of infants with clinically confirmed congenital infections was higher for IAP mothers $(p=0.0096)$. This was mainly noted in the case of the women who were not tested for GBS during pregnancy. The neonates of these mothers were significantly more often $(p=0.0076)$ diagnosed with clinically confirmed congenital infections than were the newborns of mothers not receiving treatment. Unlike Glasgow, we did not observe a significant increase in the percentage of diagnoses of clinically confirmed congenital infections in neonates born to GBS-positive mothers subjected to intrapartum antibiotic treatment, compared to the infants of untreated GBS carriers. We noticed that both treated and untreated GBS-positive mothers gave birth to a similar number of infants diagnosed with microbiologically negative intrauterine infections (5.83\% vs. $3.03 \%$ ). Furthermore, we found, similarly to Glasgow et al., that clinically confirmed intrauterine infections were more often diagnosed in neonates born via C-section than in those born vaginally $(p=0.0001)$.

What is alarming is - as Glasgow et al. suggest - an upward trend among paediatricians to use antibiotic treatment, and to diagnose microbiologically negative intrauterine infections in neonates born to mothers receiving intrapartum antibiotic treatment for various reasons [8]. Based on several other studies concerning detectability of infections in neonates, we found that a diagnosis of early symptomatic infections is very often made mainly on the basis of neonates' clinical symptoms. The authors of the aforementioned studies claim that many physicians continue intravenous administration of antibiotics even if bacteriological smear test results are negative. They believe that more frequent use of antibiotics by paediatricians in neonates born to mothers receiving IAP may have serious clinical and economic consequences [9-11]. IAP can also contribute to negative smear results in neonates, even though they develop early symptomatic congenital infections [12-14].

\section{CONCLUSIONS}

Early symptomatic infections in neonates can develop without positive bacteriological culture results.

IAP can modify the occurrence and/or the course of clinically confirmed congenital infections. 
Empirical antibiotic treatment of infections administered during the first 24 hours does not seem to be the best solution; however, at the moment it is necessary.

The colour of amniotic fluid and the type of labour, especially when accompanied by other risk factors, may suggest an infection.

\section{DISCLOSURE}

The authors declare no conflict of interest.

\section{REFERENCES}

1. Kotarski J, Heczko PB, Lauterbach R, et al. Rekomendacje Polskiego Towarzystwa Ginekologicznego dotyczące wykrywania nosicielstwa paciorkowców grupy B (GBS) u kobiet w ciąży i zapobiegania zakażeniom u noworodków. Ginekol Pol 2008; 79: 221-223.

2. Centers for Disease Control and Prevention (CDC). Perinatal group $B$ streptococcal disease after universal screening recommendations - United States, 2003-2005. MMWR Morb Mortal Wkly Rep 2007; 56: 701-705.

3. Mercer BM, Ramsey RD, Sibai BM. Prenatal screening for group B Streptococcus. I. Impact of antepartum screening on antenatal prophylaxis and intrapartum care. Am J Obstet Gynecol 1995; 173: 837-841.

4. Mercer BM, Ramsey RD, Sibai BM. Prenatal screening for group B Streptococcus. II. Impact of antepartum screening and prophylaxis on neonatal care. Am J Obstet Gynecol 1995; 173: 842-846.

5. Peralta-Carcelen M, Fargason CA, Cliver SP. Impact of maternal group B streptococcal screening on pediatric management in fullterm newborns. Arch Ped Adolesc Med 1996; 150: 802-808.

6. Wiswell TE, Stoll BJ, Tuggle JM. Management of asymptomatic, term gestation neonates born to mothers treated with intrapartum antibiotics. Pediatr Infect Dis J 1990; 9: 826-831.

7. Balter S, Zell ER, O'Brien KL, et al. Impact of intrapartum antibiotics on the care and evaluation of the neonate. Pediatr Infect Dis J 2003; 22: 853-857.

8. Glasgow TS, Speakman M, Firth S, et al. Clinical and economic outcomes for term infants associated with increasing administration of antibiotics to their mothers. Paediatr Perinat Epidemiol 2007; 21: 338-346.

9. Escobar GJ, Li DK, Armstrong MA, et al. Neonatal sepsis workups in infants $\geq 2000$ grams at birth: A population based study. Pediatrics 2000; 106: 256-263.

10. Falciglia G, Hageman JR, Schreiber M, et al. Antibiotic Therapy and Early Onset Sepsis. NeoReviews 2012; 13: 86.

11. Luck S, Torny M, d'Agapeyeff K, et al. Estimated early-onset group B streptococcal neonatal disease. Lancet 2003; 361: 1953-1954.

12. Barber EL, Zhao G, Buhimschi IA, et al. Duration of intrapartum prophylaxis and concentration of penicillin $\mathrm{G}$ in fetal serum at delivery. Obstet Gynecol 2008; 112: 265-270.

13. Bloom SL, Cox SM, Bawdon RE, et al. Ampicillin for neonatal group B streptococcal prophylaxis: how rapidly can bactericidal concentrations be achieved. Am J Obstet Gynecol 1996; 175: 974-976.

14. Łopaciuk U, Dzierżanowska D. Bakteryjne zakażenia krwi współczesne poglądy na etiologię, rozpoznawanie i leczenie. Kompendium Med 2001; 1: 11-21. 